AUSTRALIAN JOURNAL OF BASIC AND
APPLIED SCIENCES
EISSN: $2309-8414$
DOI: $10.22587 /$ ajbas.2017.11.14.2
Journal home page: www.ajbasweb.com

\title{
Analysis of Conflicts of Use and Land Coverage In Priority Areas of Conservation In The Mata Atlântica Biome
}

${ }^{1}$ Bruna Oliveira Simões, ${ }^{1}$ Elisiane Alba, ${ }^{1}$ Juliana Marchesan, ${ }^{1}$ Eliziane Pivoto Mello, ${ }^{2}$ Emanuel Araújo Silva, ${ }^{3}$ Rudiney Soares Pereira

${ }^{I}$ Postgraduate in Forestry Sciences, Federal University of Santa Maria, Santa Maria, RS, Brazil.

${ }^{2}$ Department of Forest Sciences, Federal University Rural of Pernambuco, Recife - PE, Brazil.

${ }^{3}$ Department rural engineering, Federal University of Santa Maria, Santa Maria - RS, Brazil.

\section{Address For Correspondence:}

Bruna Oliveira Simões, Federal University of Santa Maria, Postgraduate in Forestry Sciences, Av. Roraima, 1000, Camobi, 97105-900,

Santa Maria, RS, Brazil.

Phone: +55(55)97184829; E-mail: brunasimoess@hotmail.com

\section{ARTICLE INFO}

\section{Article history:}

Received 12 October 2017

Accepted 22 November 2017

Available online 6 December 2017

Keywords:

remote sensing, GIS, permanent

preservation areas, Sentinel images

\begin{abstract}
A B S T R A C T
Objective: This work was elaborated with the objective of delimiting the areas of permanent preservation along the Arroio Pessegueiro Hydrographic Sub-Basin, as a marginal strip, around springs and declivity above $45^{\circ}$, as well as possible conflicts between uses using Sentinel data. Material and Methods: For this to be possible, images of the Sentinel 2A satellite of the year 2017 were used. The images were classified into five classes of land use and cover: Forest, Agriculture, Soil Exposure, Field and Water. The digital classification of the images was carried out in the extension for semi-automatic supervised classification (SCP), incorporated in the open source program QGis. Results: Land use and land use classification showed that $43.76 \%$ of the area is occupied by forest class, $33.24 \%$ by field, $14.40 \%$ by agriculture, $8.34 \%$ exposed soil and $0.26 \%$ by water. With the crossing of maps one obtained the conflict of use and coverage of the land with areas of permanent preservation. This analysis showed the predominance of the forest class, occupying $65.05 \%$ in the total area, followed by the field, which presented $23.29 \%$, agriculture $4.78 \%$, soil exposed $5.81 \%$ and water $1.07 \%$. Conclusion: With this study, it was concluded that $35.35 \%$ of the permanent preservation areas are in breach of the legislation.
\end{abstract}

\section{INTRODUCTION}

Brazil stands out as a country with great biodiversity, especially the Atlantic Forest biome, which represents one of the richest ecosystems in the world. Due to the high rates of wealth and endemism, this ecosystem is considered one of the 25 biodiversity hotspots in the world (Campanili and Schaffer, 2010), being responsible for the quality of life of thousands of Brazilians.

Originally the biome stretched over an area of approximately 1,300,000 $\mathrm{km}^{2}$, covering 17 Brazilian states, but since the Brazilian colonization has been destroyed throughout history. Its fragmentation process reached critical levels because of the predatory extraction of forest products (Maciel, 2007). Currently the biome comprises about $22 \%$ of its original coverage. However, only $8.5 \%$ are conserved in fragments above 100 acres (Inpe, 2016; SOS Mata Atlântica, 2016).

According to studies carried out byCordeiro and Hasenack (2009) and Marchesan (2017), the Atlantic Forest biome is highly fragmented, which contributes to the loss of ecosystem functions. Accordingly, Decree law 5.092, dated May 21, 2004, assignedto the Ministry of Environment the priority areas for the conservation, sustainable use and sharing of the benefits of biodiversity. In respect to the priority areas, three priority classes for biodiversity conservation were defined: high, very high and extremely high. Therefore, we highlight the Sentinel images for monitoring the forest cover, which present high spatial resolution and free acquisition.

Open Access Journal

Published BY AENSI Publication

(C) 2017 AENSI Publisher All rights reserved

This work is licensed under the Creative Commons Attribution International License (CC BY).

http://creativecommons.org/licenses/by/4.0/

\section{Open Access}

To Cite This Article: Bruna Oliveira Simões, Elisiane Alba, Juliana Marchesan, Emanuel Araújo Silva, Rudiney Soares Pereira., Analysis of Conflicts of Use And Earth Coverage In Priority Areas of Conservation In The Mata Atlântica Biome. Aust. J. Basic \& Appl. Sci., 11(14): 9-16, 2017 
The middle region of the Rio Grande do Sul states need more research that demonstrates the state of preservation of protected areas under Brazilian law, especially the areas classified as extremely high for the conservation of the biodiversity of the Atlantic Forest biome. As well as the identification of interventions caused by the anthropic action in the modification of the original vegetation and possible noncompliance with the current legislation described in the Forest Code.

The PessegueiroStream hydrographic Sub-Basin is an affluent of the Jaguari River, one of the most important rivers in the western region of Rio Grande do Sul. The Pessegueiro Stream covers areas of three municipalities Jaguari, Jari and Mata. This region is classified as a priority area classified as extremely high for biodiversity conservation.

In this context, for a better understanding of the areas of permanent preservation, in the Pessegueiro Stream Hydrographic Sub-Basin, which is in an area of extremely high conservation priority, it is fundamental for actions that aim at the preservation of natural environments of the Atlantic Forest biome.

The objective of this work was to delineate the areas of permanent preservation along the Pessegueiro Stream Hydrographic Sub-Basin, such as marginal river range and slope above $45^{\circ}$, as well as possible conflicts of use Sentinel-2A data.

\section{MATERIAL AND METHODS}

\section{Field of study:}

The sub-basin of the Pessegueiro Stream cover areas of three cities, being them Jaguari, Jari and Mara (Figure 1) The area studied is located in the middle-west of the state of Rio Grande do Sul, between the geographic coordinates $29^{\circ} 38^{\prime} 83^{\prime \prime}$ ' and 29 $46^{\prime} 58^{\prime \prime}$ 'South latitude; $54^{\circ} 51^{\prime} 23^{\prime \prime}$ and $54^{\circ} 36^{\prime} 52^{\prime \prime}$ ' west longitude of the Greenwich Meridian, occupying an area of 8407,38 acres, which integrates the Jaguari River hydrographical basin.

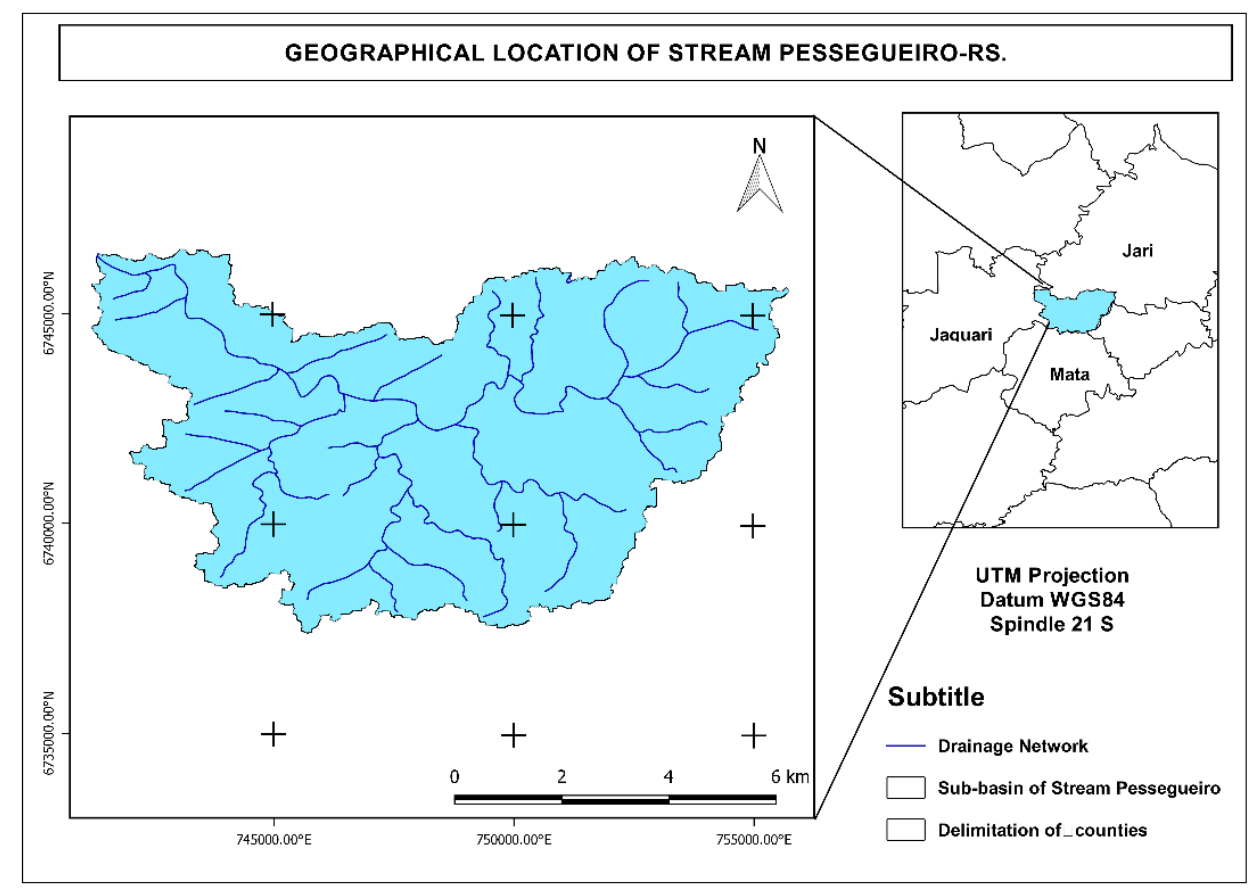

Fig. 1: Location of the Pessegueiro Stream Hydrographic Sub-Basin.

The climate of the region, as classified of Köppen-Gieger is subtropical humid (Cfa), with temperatures varying between $14^{\circ} \mathrm{C}$ and $25^{\circ} \mathrm{C}$, rainfall, on its turn, are distributed during the year, presenting an annual average of 1,700mm (Moreno, 1961), and it is inserted in the geomorphological region of the Peripheral Depression, and South's Rio Grande do Sul Plateau. The predominant original vegetation of this region is called the Deciduous Seasonal Forest, but currently there are only leftovers of this native formation (Marchiori, 2002).

\section{Method:}

The orbital image of the Sentinel-2A satellite, MSI (Multi-Spectral Instrument) sensor, with 10 meter spatial resolution used in this study was purchased free of charge from the United States Geological Survey (USGS). The selected image selected is dated 31January 2017. This study had SRTM (Shuttle Radar 
Topography Mission) radar images, with spatial resolution of $30 \mathrm{~m}$. The SRTM images were initially set as mosaic and thus used for automatic delimitation of the study area, which was performed in the Qgis-Quantum GIS Geographic Information System (Qgis Development Team, 2016) version 2.14, through modules integrated with the GRASS program (Watershed), which are based on edges detection for the river basin delimitation.

The digital classification of the Sentinel image was performed in the extension for semiautomatic supervised classification - SCP (Semi-Automatic Classification Plugin), incorporated in the open-source program QGis, version 2.14.11. The band was adjusted to obtain the true composition with based on bands 4,3 , 2 (RGB) that were contrasted in order to provide better visual comfort in order to identify the targets present in the image.

For the accomplishment of the classification, a training file was created based on samples of acquisition and test, containing the spectral signatures, thus targets were created and linked to macro-classes. In this process some parameters were defined as the Range Radius of 0.04000 , minimum radius size of 40 meters and maximum radius size of 100 meters. The maximum likelihood classifier (Maxver) was used, since it allows finding a pixel of a given class in a given position and associating it with a given class of land use and coverage, and threshold value equal to 100 .

The training process was repeated until sufficient samples were obtained for the correct representation of the interest classes. For greater reliability of the samples, GoogleEarthtool was used to assist on obtaining the samples, as well as for the conference of the final result. Five macro-classes of land use and cover were used: Forest, field, agriculture, unveiled soil, water.

The reliability of the mapping was confirmed by the Kappa coefficient proposed by Cohen (1960), following the methodology described by Congalton (1991). The evaluation of the classification was made using the proposal of Landis and Koch (1977) (Table 1).

Table 1: Quality of the classification according to Kappa coefficient intervals.

\begin{tabular}{l|l}
\hline ValueKappa & Qualityofclassification \\
\hline$<0.00$ & Poor \\
$0.00-0.20$ & Bad \\
$0.20-0.40$ & Reasonable \\
$0.40-0.60$ & Good \\
$0.60-0.80$ & VeryGood \\
$0.80-1.00$ & Excellent \\
\hline Font Landis and Koch (1977)
\end{tabular}

Font: Landis and Koch (1977)

For the definition of permanent preservation areas, the Sub-Basin's marginal strip was considered, around its sources and slopes above 45 degrees, according to criteria established by the legislation, Conama Resolution number 303/2002, and in the Forest Code (Lei 12.651, 2012). For the delimitation of PPAs along the watercourse, it was defined preservation areas in 0 to $10 \mathrm{~m}, 0$ to $20 \mathrm{~m}$ and 0 to $30 \mathrm{~m}$ bands, identifying the degree of adequacy of the producers with the current legislation. It was also identified the slopes with slopes greater than 45 degrees.

The map of environmental conflicts was based on the overlapping of the map of land use and land cover with the map of APPs in watercourses, springs and hilltop, through the post-processing where the crossclassification of the images was performed, using extension to semiautomatic supervised classification - SCP (Semi-Automatic Classification Plugin). The final elaboration of the thematic maps was developed in the Qgis software.

\section{RESULTS AND DISCUSSION}

\section{Use and land cover:}

The mapping of the land use and coverage generated through the semi-automatic supervised SCP classification of the Sentinel 2A image allowed the identification of the land use and occupation forms, in a fast and reliable manner, which can be observed in Figure 4. The result of the index Kappa was $0.825(82.5 \%)$ therefore it is ranked as "excellent". 


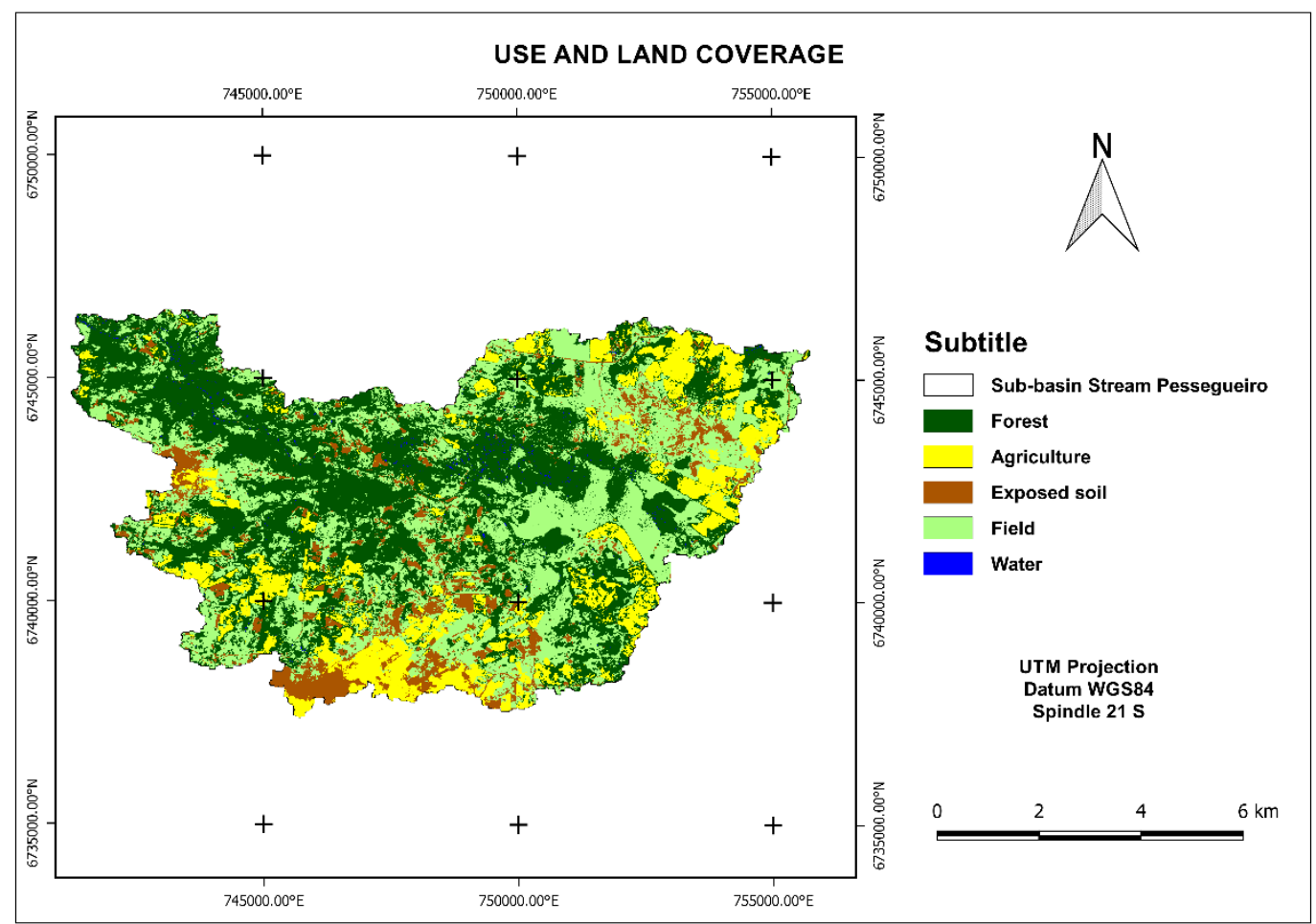

Fig. 2: Land use and land cover map for the year 2017, for Pessegueiro Stream Hydrographic Sub-Basin.

From the mapping, the measurements of each class were obtained (Table 2). It is possible to identify the current characteristics of the area and the percentage that each class occupies in the study area. Data analysis for the year 2017 showed that the forest class covered most of the study area, occupying 3,679.39 acres, equivalent to $43.76 \%$ of the total, being this one composed of Seasonal Forest reminiscence of the Mata biome Atlantic.

Table 2: Quantification of the thematic classes of the Pessegueiro Stream Hydrographic Sub-Basin.

\begin{tabular}{l|ll}
\hline \multirow{2}{*}{ Thematic Classes } & 2017 & $\%$ \\
\cline { 2 - 3 } & Area (ha) & 43.76 \\
Forest & $3,679.39$ & 14.40 \\
Agriculture & $1,211.02$ & 8.34 \\
Exposedsoil & 700.8 & 33.24 \\
Field & $2,794.34$ & 0.26 \\
Water & 21.83 & 100.00 \\
Total & $8,407.38$ & \\
\hline
\end{tabular}

Field areas, consisting of grasses, are occupied for livestock purposes. They were found in 2,794.34 acres, corresponding to $33.24 \%$ of the area. The exposed soil class occupied 700.8 acres (8.34\%), emphasizing that this class also represents fallow land.

The agriculture class comprised 1,211.02 acres (14.40\%), corroborating with Santos (2010), which states that agricultural production is not intensified in the region due to the type of soil present, which consists of an underdeveloped soil. For the water class, the percentage of $0.26 \%$ were found, 21.83 acres of the total area, this class being associated with the presence of rivers and reservoirs in the study area.

\section{Areas of permanent preservation:}

The sub-basin has a total permanent preservation area equal to $1,208.65$ acres, while 981.31 ha $(79.97 \%)$ are permanent preservation areas along the watercourses (Figure 3), and 227, 34 acres (18.53\%) correspond to areas with slopes greater than 45 degrees (Figure 4). 


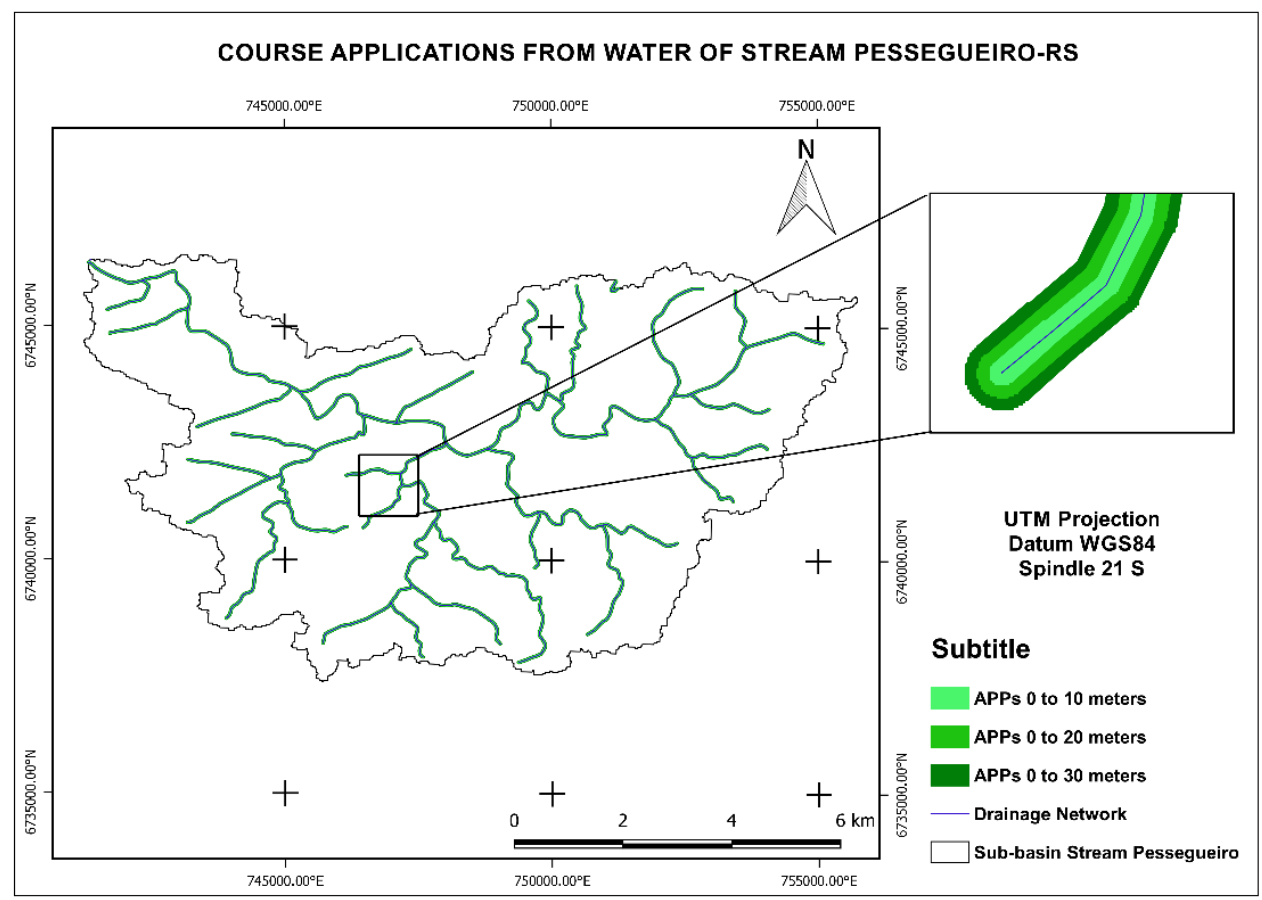

Fig. 3: APP ranges of watercourses of the Pessegueiro Stream Hydrographic Sub-Basin.

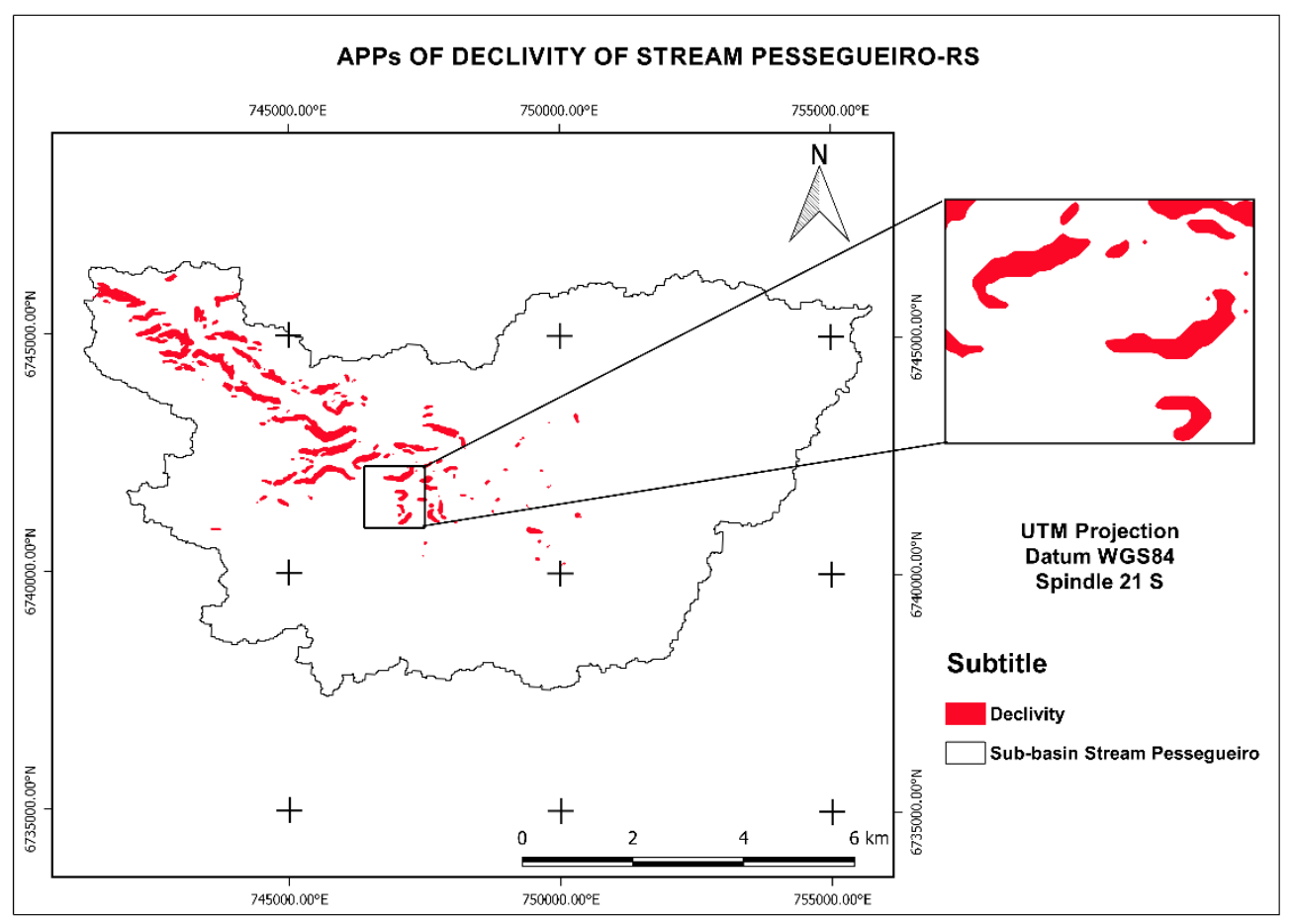

Fig. 4: Map of APPs in slope greater than $45^{\circ}$ in the Pessegueiro Stream Hydrographic Sub-Basin.

\section{Conflicts of uses and land cover:}

The existing conflicts in the sub-basin were defined based on the cross-map use and coverage with the PPA maps of watercourses and slope. Thus, it was identified the possible conflicting uses and in which areas the native vegetation of the biome was not present, being in disagreement with the Brazilian legislation.

In Table 3 we can verify the quantification of the conflict areas in Permanent Preservation Areas situated in the rivers courses. Thus, 638.33 acres, equivalent to $65.05 \%$, are occupied by native forest vegetation of the biome, while 228.58 acres $(23.29 \%)$ of PPA are being occupied by the field class. With lower percentage, agriculture was identified in 46.9 acres $(4.78 \%)$, and still 56.99 acres (5.81\%) occupied by exposed soil. 
The areas that are occupied by forest and water summed combined the amount of (65.05\%) and 10.5 acres $(1.07 \%)$ respectively; these two classes are not considered conflicting. The conflicting ones are the result of human intervention.

Table 3: Conflict of the areas of permanent preservation in the water courses.

\begin{tabular}{l|ll}
\hline \multirow{2}{*}{ Thematic Classes } & Areas of Permanent Preservation & \\
\cline { 2 - 3 } & Área (ha) & 65.05 \\
\hline Forest & 638.33 & 4.78 \\
Agriculture & 46.90 & 5.81 \\
Exposed soil & 56.99 & 23.29 \\
Field & 228.58 & 1.07 \\
Water & 10.51 & 100.00 \\
\hline Total & 981.31 & \\
\hline
\end{tabular}

The areas of permanent preservation are of extreme importance for a river basin, since most of them are characterized by riparian forests, which are in charge of the conservation and maintenance of the basin, avoiding erosive processes, which can lead to their silting (Nardini, 2009). PPAs are protected by law, however noncompliance, can cause irreversible damage to the environment, such as silting and pollution of rivers.

Among these areas, PPA ranges were analyzed with a distance of 0 to 10 meters, 0 to 20 meters and 0 to 30 meters. The bands can be seen in Figure 5.It can be observed that of both bands, the native forest class predominated. In this way, the 0 to 10 meter range is known to occupy 108.6 acres of the total area of the strip, and the forest increment for the PPAs from 0 to 20 meters and 0 to 30 meters, resulted in 106.16 acres and 100.21 acres, respectively. The range from 0 to 30 meters was shown to be of less value than the others, this behavior is possibly associated with the area of coverage being greater than the other ranges (Table 4).

Table 4: Areas of permanent preservation for distance from 0 to 10 meters, 0 to 20 meters and 0 to 30 meters, in hectares.

\begin{tabular}{l|lll}
\hline \multirow{2}{*}{ Thematic Classes } & Areas of Permanent Preservation (ha) & $30 \mathrm{~m}$ \\
\cline { 2 - 4 } & $10 \mathrm{~m}$ & $20 \mathrm{~m}$ & 314.97 \\
Forest & 108.6 & 214.76 & 24.40 \\
Agriculture & 7.33 & 15.17 & 28.47 \\
Exposed soil & 9.53 & 18.99 & 114.28 \\
Field & 37.81 & 76.49 & 5.07 \\
Water & 1.84 & 3.60 & 487.19 \\
\hline Total & 165.11 & 329.01 & \\
\hline
\end{tabular}

In Figure 5 we can observe the values of each PPA range in percentage, corresponding to the amount of native forest in relation to the total area of each strip.

The native forest occupied $65.77 \%$ of the total area encompassed by the PPA from 0 to 10 meters, where the remaining part identified as other uses as shown in Figure 7. For the range of 0 to 20 meters the area occupied by the native vegetation was of $65.27 \%$, while PPA from 0 to 30 meters covered $64.65 \%$ of native forest. Analyzing the areas occupied by other uses, it was verified that the PPA of 0 to 10 meters comprises $34.23 \%$ of the total area, $34.73 \%$ of the range of 0 to 20 meters and for the distance of 0 to 30 meters resulted in $35.35 \%$ (Figure 6).

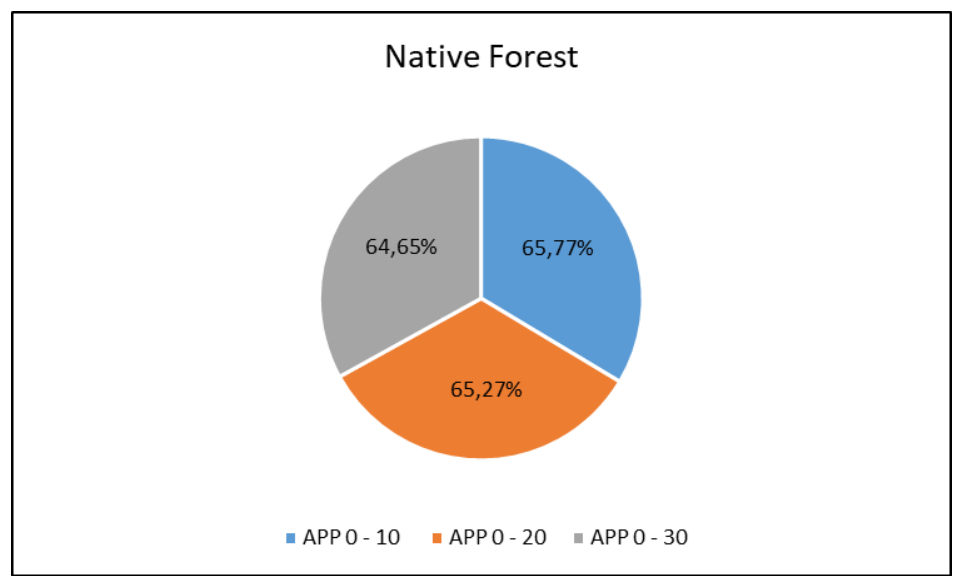

Fig. 5: Percentage values of Native Forest in the APP bands. 


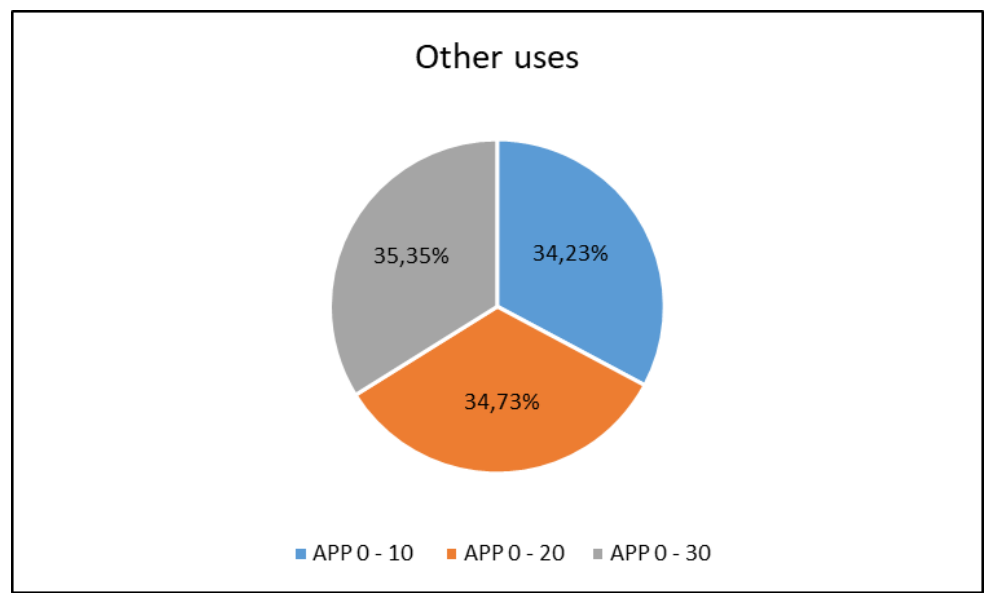

Fig. 6: Percentage values of other uses in the APP bands.

In this way, it is understood that the PPA from 0 to 10 meters, is where most of the native forest is located in relation to the total area with $65.77 \%$. In the range of 0 to 30 meters, it presents a higher value of area encompassed by other uses, that is, $35.35 \%$ is in non-compliance with forest legislation.

For permanent preservation areas located at a slope greater than 45 degrees (Figure 8), it was observed that forests predominated in 213.17 acres $(93.77 \%)$, where the field class occupied 12.41 acres (5.46 \%), soil exposed and agriculture values were 0.18 acres $(0.08 \%)$ and 1.58 acres $(0.69 \%)$, respectively. Water areas were not found in slopes greater than 45 degrees (Table 6).

Table 6: Conflict of permanent preservation areas with slopes greater than 45 degrees.

\begin{tabular}{l|ll}
\hline \multirow{2}{*}{ Thematic Classes } & Declivity> $45^{\circ}$ & $\%$ \\
\cline { 2 - 3 } & Area (ha) & 93.77 \\
\hline Forest & 213.17 & 0.69 \\
Agriculture & 1.58 & 0.08 \\
Exposed soil & 0.18 & 5.46 \\
Field & 12.41 & 0.00 \\
Water & 0.00 & 100.00 \\
\hline Total & 227.34 & \\
\hline
\end{tabular}

In the study developed by Luppi et al., (2015), it was verified that in the town of João Neiva, the PPA of hill top occupied $23.01 \%$ of the study area. However, $59.02 \%$ of PPA areas are pasture-occupied, evidencing non-compliance with legislation and environmental resolutions.

Likewise, the results obtained by Nardini (2009) are in agreement with the study by Luppi et al. (2015), in such a way that the microbasin of RibeirãoÁgua Fria presents high anthropization, since natural forests represent only $32.36 \%$ of the total area. The study also shows that the buffer zones in PPA in the watershed represent 343.07 acres, of which approximately $88 \%$ correspond to pastures.

For the study area of the Alegre River -ES hydrographic basin, Nascimento et al. (2006) found that mapped land use classes are partially located in legally protected areas, especially those resulting from anthropogenic actions. The authors observed that $78.39 \%$ of the PPAs are being affected by misuse, while $21.6 \%$ are covered by native forest fragments.

In this sense, the present study demonstrates the need for actions to control the illegal exploitation of protected areas for the preservation of local biodiversity. The importance of awareness campaigns regarding the relevance and benefits of PPA maintenance is highlighted, especially in the Atlantic Forest biome, which continues to be exploited, favoring the loss of species endemic to these environments.

\section{Conclusion:}

Using the images from the Sentinel-2A satellite, MSI sensor,it was possible to quantify land use and land cover classes and permanent preservation areas. The use of the semiautomatic supervised classification - SCP, and the parameters used for the mapping, obtained satisfactory results, representing the compatibility to the reality of the study area.

It was identified that approximately $35 \%$ of the PPA of the Pessegueiro Stream Sub-Basin is being used for anthropic uses, with non-compliance with Law 12,651/2012, where these areas should be protected, causing environmental damages in the sub-basin. The main nonconformities were found in water flow when compared to areas with a slope greater than $45^{\circ}$. 


\section{REFERENCES}

Alba, E., R.S. Pereira, P.A.Bellé, J. Marchesan, E.P. Mello, E.A. Silvaand T.L. Badin, 2016. Atmospheric correction evaluation in the mapping of forest stands with OLI/Landsat 8 images. Australian Journal of Basic and Applied Sciences, 10(16): 185-191.

Brasil., 2012. Novo Código Florestal. LEI No 12.651, DE 25 DE MAIO DE 2012. Brasília, DF, 25 de maio de 2012. Disponível em: <http://www.planalto.gov.br/ccivil_03/_ato2011-2014/2012/lei/112651.htm>. Acesso em: 24 de março de 2017.

Brasil., 2002. Resolução do CONAMA 303, de 20 de março de 2002,Dispõe sobre os parâmetros, definições e limites de Áreas de Preservação Permanente. Brasília, DF: Congresso Nacional. MMA.

Campanili, M. andW.B. Schaffer, 2010. Mata Atlântica: patrimônio nacional dos dos brasileiros. Brasília:

Cohen, J.A.,1960. Coeficient of agreement for nominal scales. Journal of Educational and Measurement, Washington, 20(1): 37-46.

Cordeiro, J.L.P. and H. Hasenack, 2009.Cobertura vegetal atual do Rio Grande do Sul. In: PILLAR, V. P.; MUlleR, S. C.; CASTILHOS, Z. M. S.; JACQUES, A. V. A. (Org.). Campos sulinos: Conservação e uso sustentável da biodiversidade. Brasília: MMA, cap. 23: 285-299.

Espirito, S., 2006. ARES: atlas das áreas com potencial de riscos do Estado do Espírito Santo. Vitória: Imprensa Estadual, pp: 125.

Landis, J., G.G. Koch, 1977. The measurements of agreement for categorical data. Biometrics, Washington, 33(3): 159-179. INPE - Instituto Nacional de Pesquisas Espaciais. Disponível em: <http://www.inpe.br>. Acesso em: 01 ago. 2016.

Luppi, A.S.L., A.R. Santos, F.C. Eugenio and L.S. Feitosa, 2015. Utilização de Geotecnologia para o Mapeamento de Áreas de Preservação Permanente no Município de João Neiva.Floresta e Ambiente, 22(1): 1322.

Maciel, B.A., 2007. Mosaicos de Unidades de Conservação: Uma estratégia de conservação para a Mata Atlântica.007. 182 p. Dissertação (Mestrado em Desenvolvimento Sustentável) - Universidade de Brasília, Brasília.

Marchesan, J., 2017. Análise Espacial da Fragmentação Florestal em Áreas do Bioma Mata Atlântica Utilizando Linguagem R. 2017. 127p. Dissertação (Mestrado em Sensoriamento Remoto) - Universidade Federal de Santa Maria. Santa Maria, RS.

Marchiori, J.N.C., 2002. Fitogeografia do Rio Grande do Sul: enfoque histórico e sistemas de classificação. Porto Alegre: Ed. EST, p: 118.

Ministério do Meio Ambiente. Mata Atlântica. Disponível em: <http://www.mma.gov.br/biomas/mataatlantica>. Acesso em: 24 de março de 2017.

Moreno, J.A., 1961.Clima do Rio Grande do Sul. Porto Alegre: Secretaria da Agricultura, p: 42.

Fundação SOS Mata Atlântica, 2016. Atlas dos remanescentes florestais da mata atlântica período 20142015 - Relatório técnico - São Paulo. Fundação SOS Mata Atlântica e Instituto Nacional de Pesquisas Espaciais INPE.

Silva, E.A., E. Alba, J. Tramontina, P.A. Bellé, A.P. Finger and R.S. PEREIRA, 2017. Dynamic modeling for simulation in the sandification process in Western Rio Grande do Sul, Brazil. Australian Journal of Basic and Applied Sciences, 10(18): 137-142. 